\title{
Research Paper \\ A Comparative Study on the Effectiveness of the Verbal Self-Learning Method and Perceptual-Motor Games on the Attention Range of Hyperactive High School Students with Attention Deficit / Hyperactivity Disorder
}

\section{Samad Ghassabi ${ }^{1}$, Hasan Bafandeh Gharamaleki ${ }^{* 2}$, Alireza Mohammadi Aria ${ }^{3}$, Guita Movallali ${ }^{4}$}

1. Ph.D. Student of Psychology and Education of Exceptional Children, Faculty of Psychology, Islamic Azad University, Research Branch, Tehran, Iran

2. Assistant Professor, Department of Educational Psychology, Faculty of Psychology and Educational Sciences, Azarbaijan Shahid Madani University, Tabriz, Iran

3. Assistant Professor, Department of Preschool Education, School of Educational Sciences and Social Welfare, University of Social Welfare and Rehabilitation Sciences, Tehran, Iran

4. Associate Professor, Department of Psychology and Education of Exceptional Children, Faculty of Psychology and Educational Sciences, University of Social Welfare and Rehabilitation Sciences, Tehran, Iran

Citation: Ghassabi S, Bafandeh Gharamaleki H, Mohammadi Aria A, Movallali G. A comparative study on the effectiveness of the verbal selflearning method and perceptual-motor games on the attention range of hyperactive high school students with attention deficit / hyperactivity disorder. Quarterly Journal of Child Mental Health. 2020; 7(1): 281-294.

$\underline{\text { http://dx.doi.org/10.29252/jemh.7.1.24 }}$

\section{A R T I C L E I N F O}

\section{Keywords:}

Verbal self- instruction, perceptual-motor games, attention span

Received: 21 Aug 2018

Accepted: 13 Dec 2018

Available: 20 Jun 2020

\begin{abstract}
A B S T R A C T
Background and Purpose: Students with attention deficit/hyperactivity disorder (ADHD) are among those who are faced extra problems in executive functions and cognitive processes such as memory and attention. They have also some difficulties in problem-solving and everyday life situations. The purpose of the present study was to compare the effectiveness of verbal selfinstruction method with perceptual-motor games on the range of attention of the ADHD students in Tabriz city, Iran.

Method: This research was a semi-experimental and pre-test/post-test one with the control group. The statistical population were all male primary school students in the city of Tabriz in the academic year of 2017-18. They were selected through DSM-5 diagnostic criteria and Children symptoms questionnaire (CSI-4). A random cluster sampling method was used and 60 students with ADHD were randomly selected; Forthy of them were set in experimental groups and 20 in the control group. The Children symptom inventory -4 (CSI-4) (2004) was used for data collection and the multivariate covariance test was used for data analysis.

Results: The results of the single-variable and multivariate analysis of covariance showed that there was a significant difference between the scores of selective attention, sustained attention, shift and control of attention, and attention span of the students in the experimental and control groups at the post-test stage.

Conclusion: Based on the findings, it can be argued that proper interventions such as verbal selfinstruction and perceptual-motor games can be effective in addressing the problems of students with ADHD and their improvement. Perceptual-motor methods can improve visual-perceptual processing of children which in turn can improve child's cognitive skills such as attention.
\end{abstract}

\footnotetext{
* Corresponding author: Hasan Bafandeh Gharamaleki, Assistant Professor of Cognitive Neuroscience, Faculty of Psychology and Educational Sciences, Azarbaijan Shahid Madani University, Tabriz, Iran.

E-mail addresses: H_bafandeh@azaruniv.ac.ir
} 


\title{
مقايسه اثربخشى روش خودآموزى كلامى و روش بازىهاى حر كتى بر دامنه توجه دانش آموزان مبتلا به اختلال نارسايى توجه / فزون كنشى
}

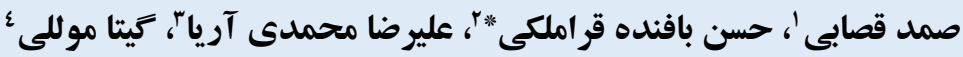

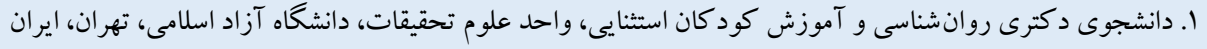

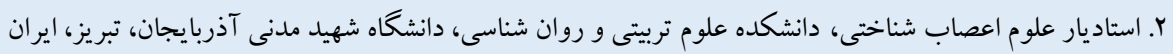

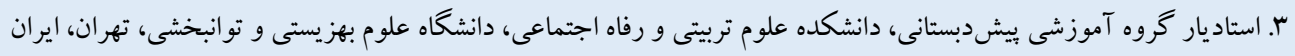

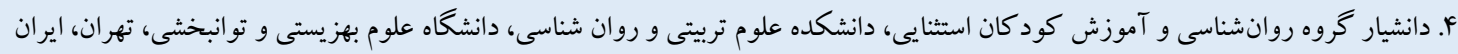

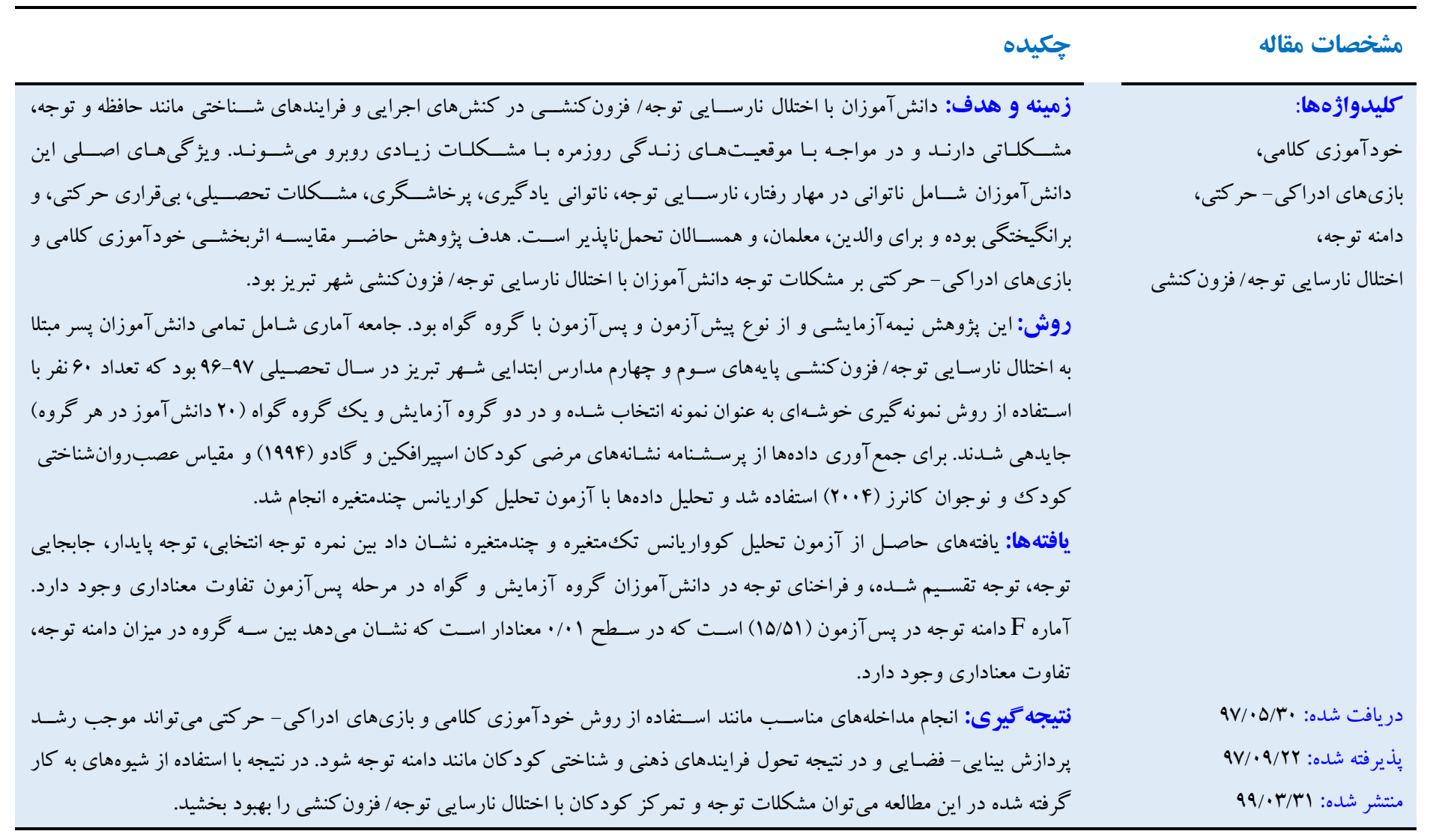

* نويسنده مسئول: حسن بافنده قراملكى، استاديار علوم اعصاب شناختى، دانشكده علوم تربيتى و روان شناسى، دانشكاه شهيد مدنى آذربايجان، تبريز، ايران.

H_bafandeh@azaruniv.ac.ir r راياناهن

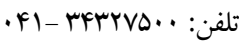


درمانى شـناختى-رفتارى در درمان كودكان و نوجوانان، روى آوردى

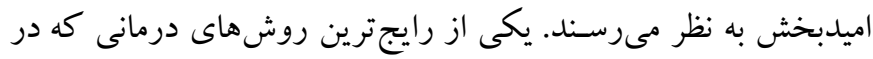

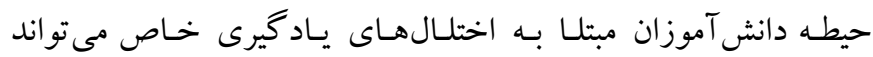

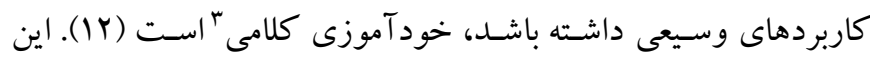

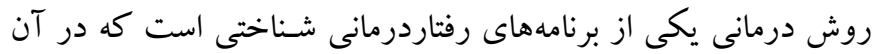

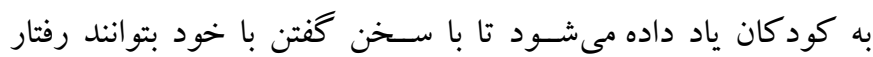

$$
\text { نامطلوب خود را تغيير دهند. }
$$

روش اخير نـاظر بر فراينـدى اســت كـه در طى آن فرد ابتـدا كفتـار

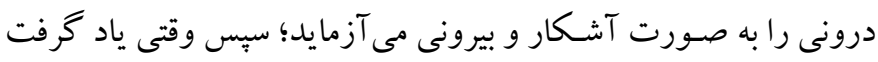
كه جه كارى بايد انجام دهد آن را به صـورت درونى انجام مىدهد و با

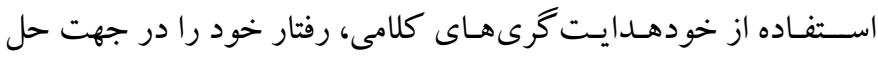

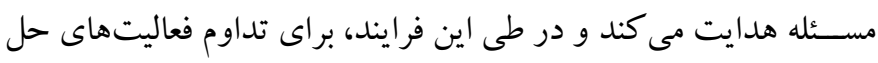

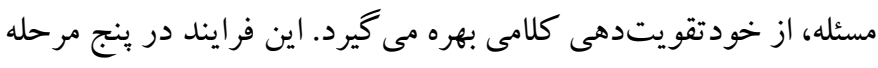

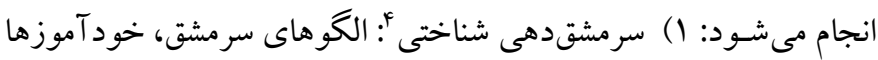

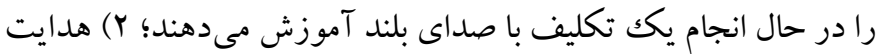
بيرونى آشـكـاره: دانش آموزان به هنگگام ارائه آموزش به وســيله معلم،

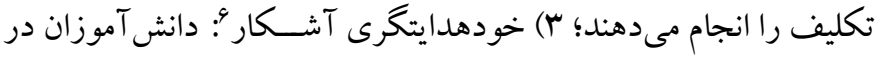

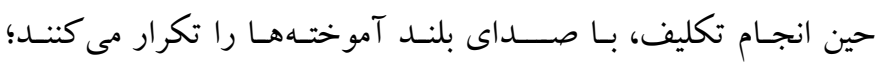

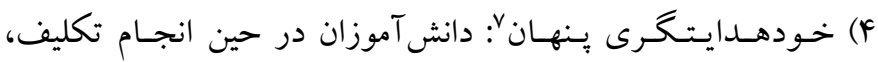

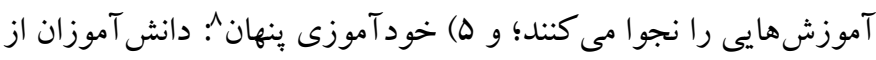

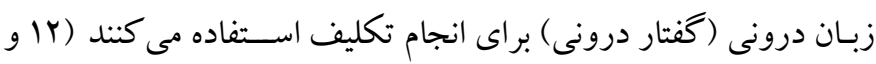

اثربخشى خود آموزى در مطالعات مختلفى بررسى شده است. براى

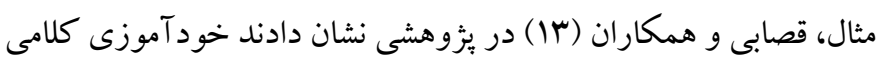

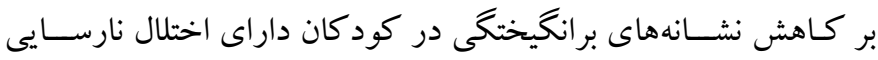
توجه / فزون كنشسى مؤثر اسـت. رونن (IF) در يكك مطالعه موردى، آثار

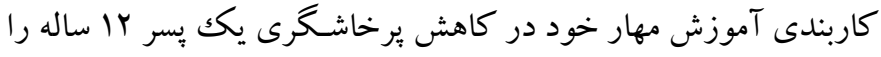

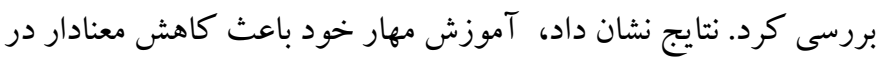
رفتـار مخرب و افزايش معنـادار در مهار خود و تعـامل هاى اجتماعى در

5. Obvious external guidance

6. Self-disclosure

7. Hidden self-guidance

8. Hidden self-learning
مقدمه

اختلال نارسـايى توجه/ فزون كنشى' يكك اختلال عصبى تحولى است كه

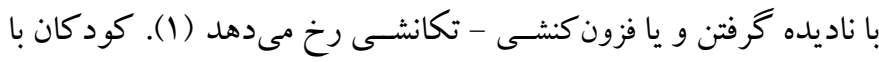

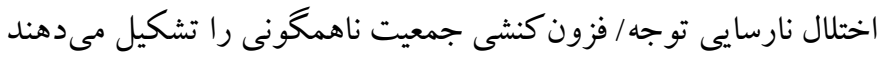

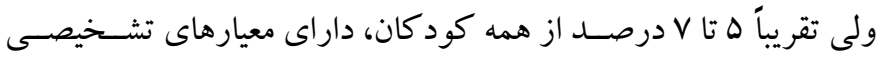

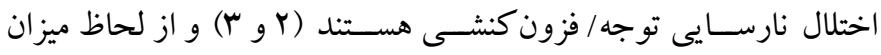

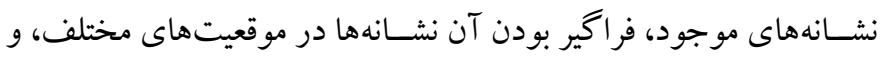

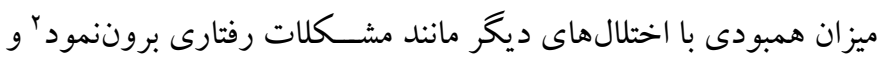

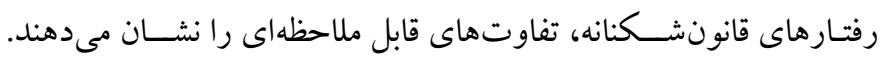

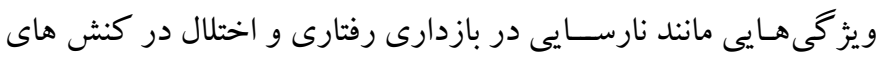
اجر ايى، مشكل اساسى كود كان داراى اختلال نارسايى توجه / فزون كنشى مانى

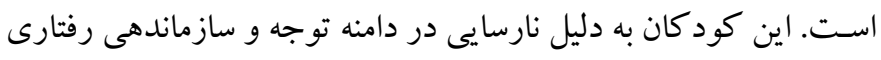

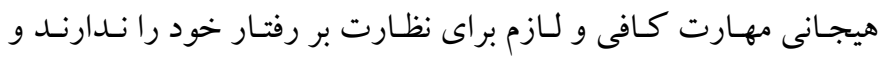
نمى تواند رفتار خود را براى زمانى طولانى تنظيم كنند (أو هاه). در نتيجه،

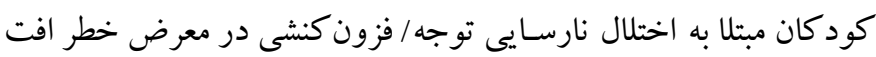

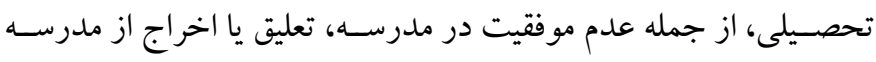

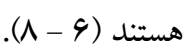

نظريـهــاى متفـاوتى در مورد اينكه جر ا كود كان نشــانههاى اختلال

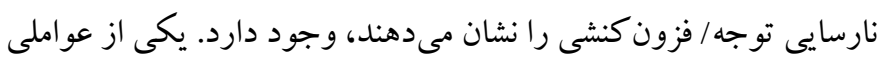

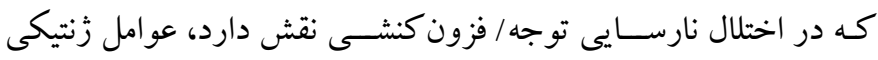

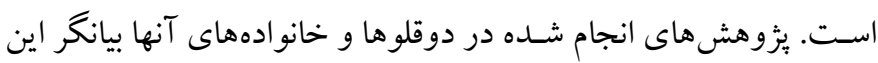

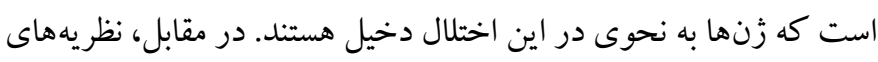

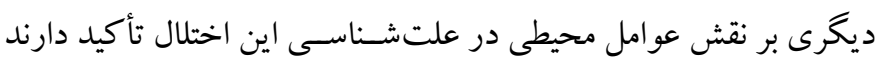

نارســايى توجه يكى از بارزترين مشــكلات كود كان مبتلا به اختلال نارسايى توجه / فزون كنشى است، به طورى كه اين ويز كى نخستين معيار

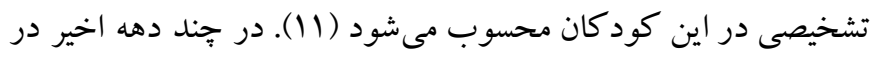

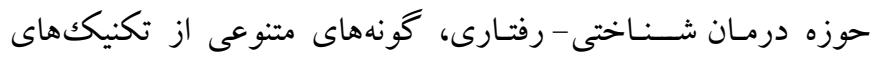
درمانى براى مواجهه با اختلال هاى روانى عرضسه شده است. برنامه هاى

1. Attention deficit hyperactivity disorder

2. Externalizing problems

3. Verbal self Instruction training

4. Cognitive role model 


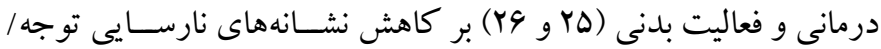
فزون كنشـى و بهبود مهارتهاى حركتى مؤثر هســنـد. با توجه به آنجه كفته شـد، نارسـايى در دامنه توجه بر عملكرد كود كان اختلال نارسـايى توجه/ فزون كنشى تأثير گذار اسـت و مىتواند اثرات مهمى بر آينده اين كود كان بخذارد و به بروز مشكلات مستقيم و غير مستقيم در ساير مراحل زندكى اين كود كان منجر شــود. در واقع تمرينات ادراكى - حركتى از طريق تسـهيل شـكل يذيرى عصسبى، ايجاد سـاختارهاى جديد سينايسى،

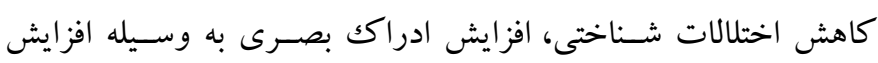

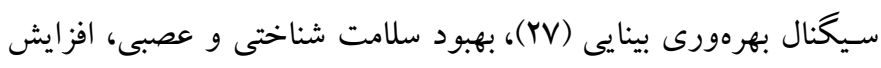
عملكرد بردازش اطلاعات، افزايش بهرهورى انتقالدهندههاى عصسبى، انطبـاق عصــى، بـازيـابى عملكرد رفتـارى، و تنظيم هيجان مىتواند بهرهورى فيزيولوزى عصسـى، تحول مغز، و تحول حركتى را بهبود بخشــ و باعث افزايش عملكرد سـيستم عصبى و عملكرد شناختى شود

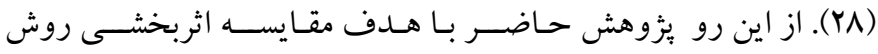
خودآموزى كلـامى و روش بـازىهـاى ادراكى - حر كتى بر دامنه توجه دانش آموزان داراى اختلال نارسايى تو جه/ فزون كنشى انجام شد.

روش الف) طرح هزوهش و شـر كت كنند كان: يزٔوهش حاضـر از نوع نيمه

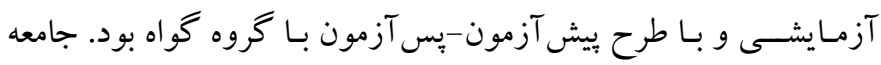

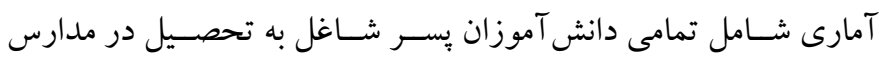

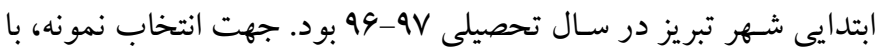

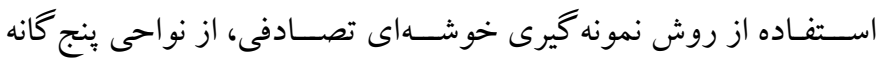

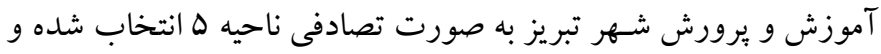

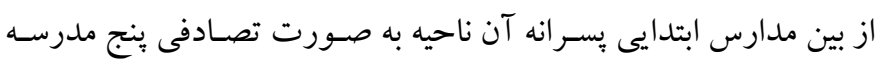

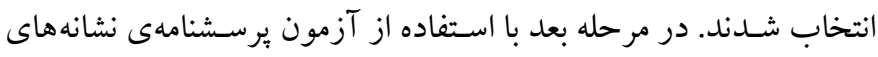

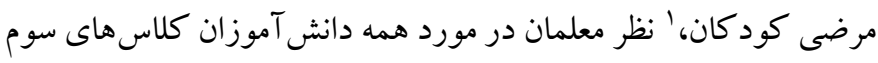

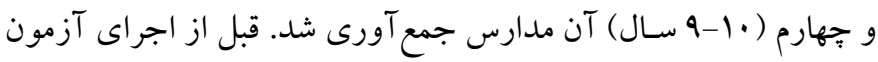

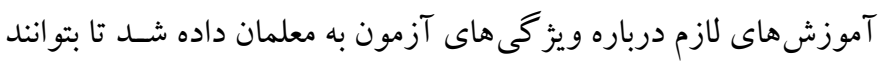

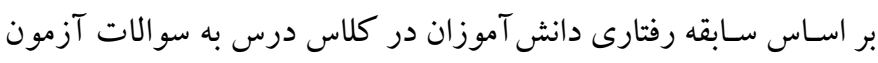

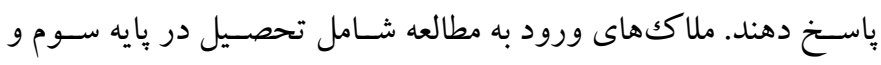

كود كان مىشـود. لينلى و جوزف (1))، خودآموزى كلامى را سـبب

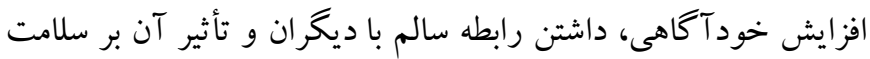

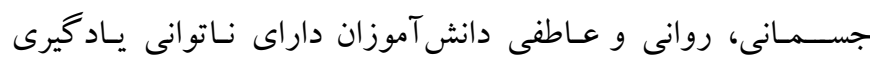

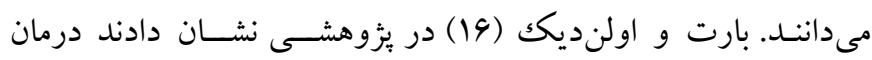

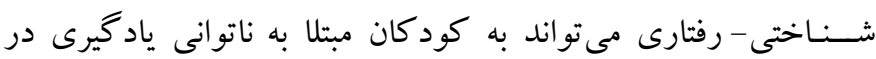

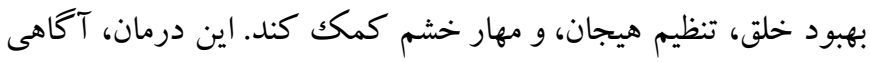

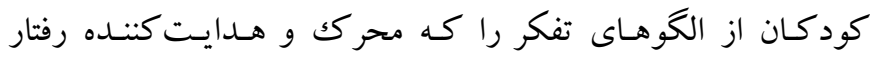
آنهاسـت، افزايش مىدهد و روشهايى را براى مقابله با تفكرشـان، به آنه آنها مى آموزد. از سـويى ديخر كود كان مبتلا به اختلال نارسايى توجه / فزون كنشى به دليل ضسف در تمر كز نمى توانند تكاليف خود را به خوبى انجام دهند و

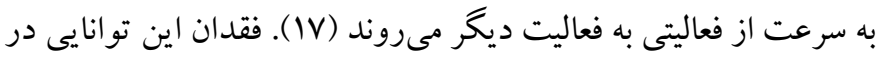

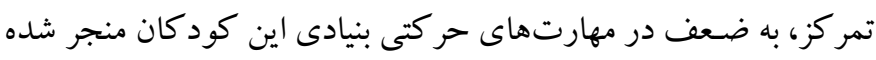

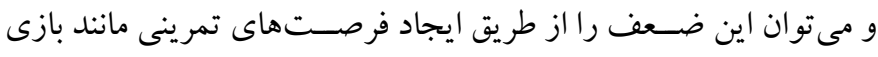

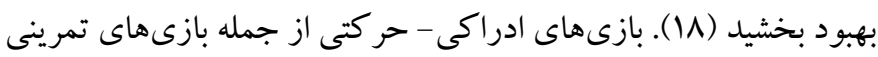

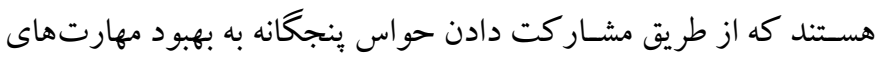

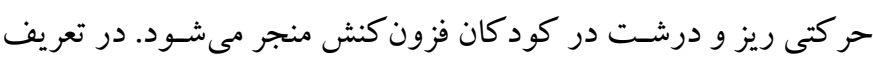

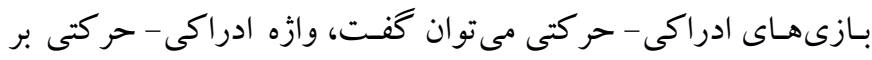
تعبير، تفسير و پاسسخخ فرد به يكك محر كى، دلالت مى كند. تجربه هاى

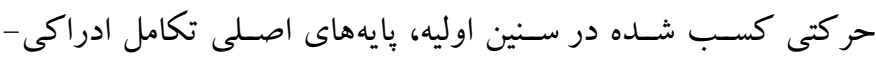

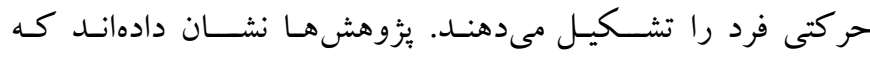

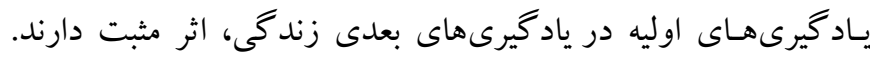

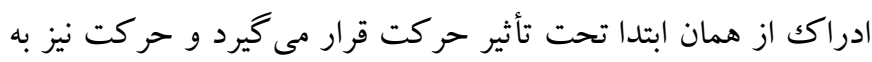

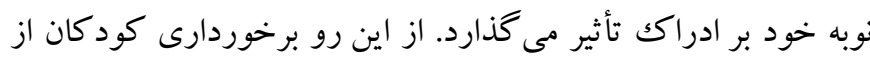

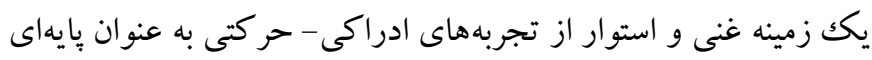

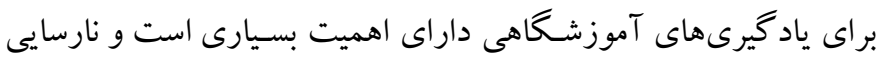

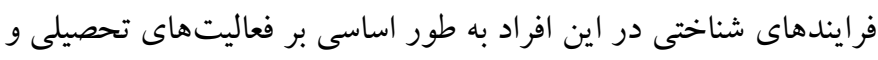

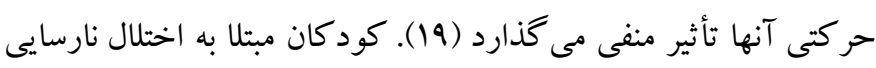

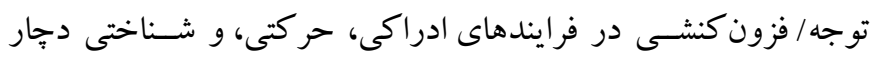

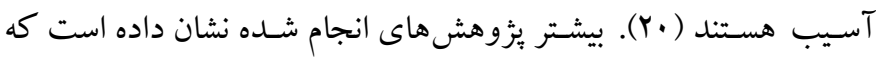

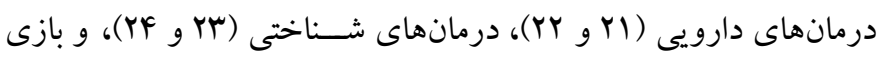


نافرمانى، رفتار هنجارى، اضطرابى و تيك،، روانگسستگى، خلقى، اختلال

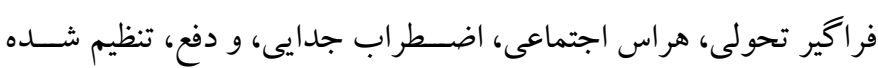

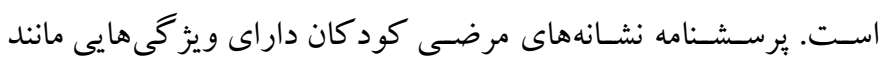

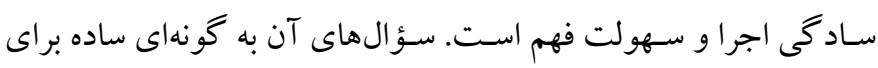

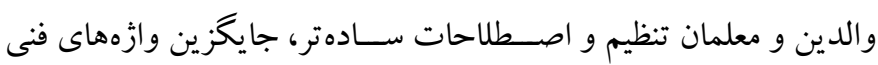

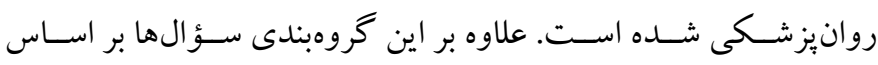

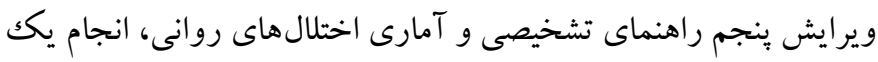

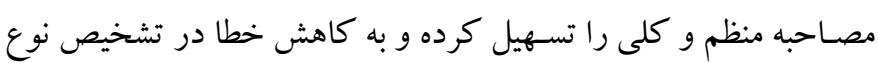

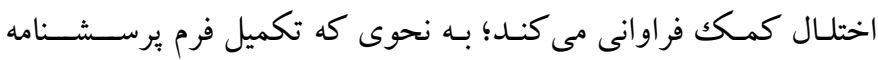
نشـانههاى مرضسى كود كان توســ و الدين در حدود لـا تا ها دقيقه و

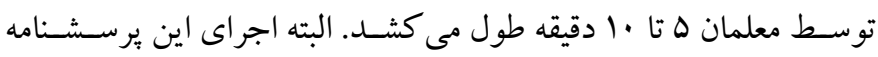

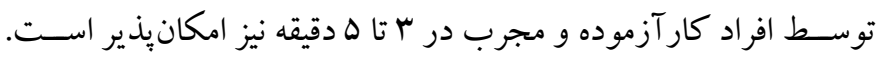

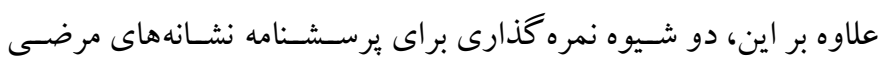

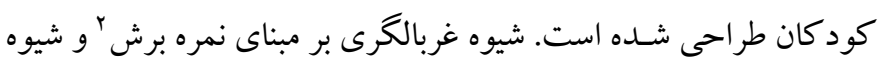

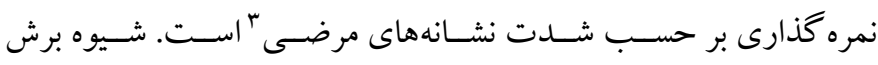

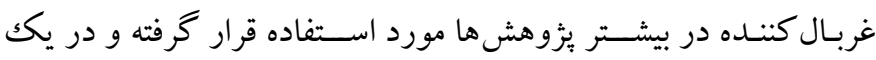

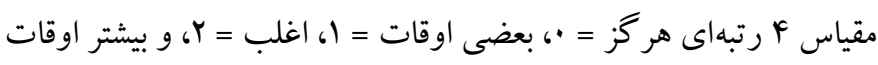

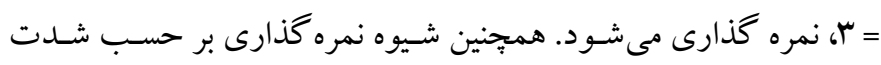

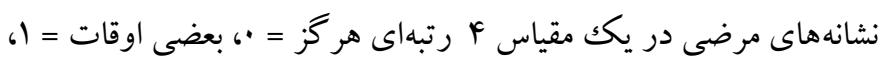

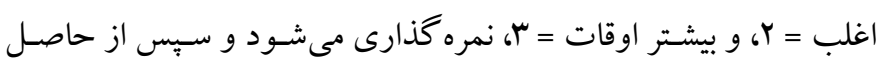

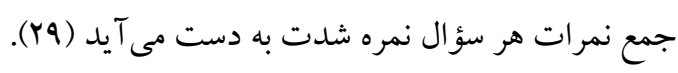

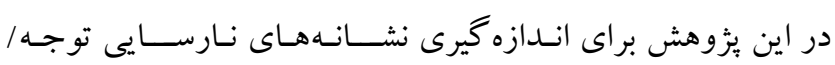

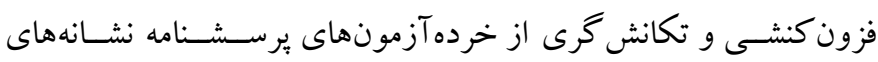

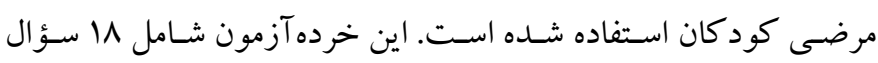

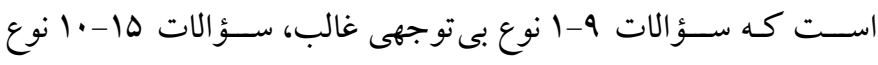

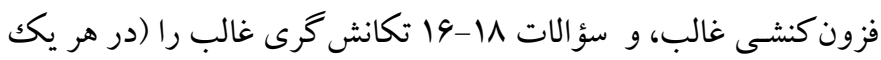
از يرسشنامههاى والد و معلم) شناسايى مى كند.

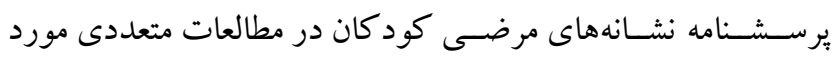

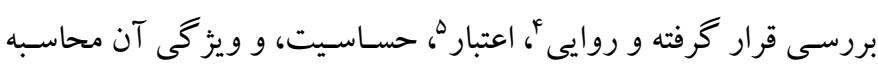

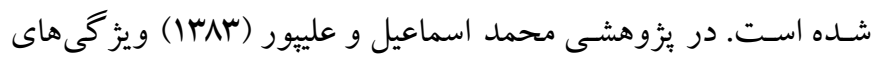

4.Validity

5. Reliability
جهارم دبسـتان، تشـخيص اختلال نارسـايى توجه/ فزون كنشسى از طريق مصساحبه تشـخيصى بر اسـاس ملاككهاى راهنماى تشـخيصى و آمارى اختلال هاى روانى و كسب نمرات بالاى نمره برش با در ير سشنامه علايم

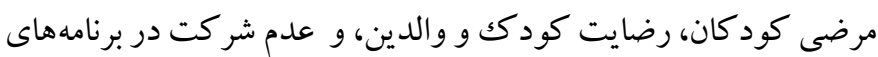

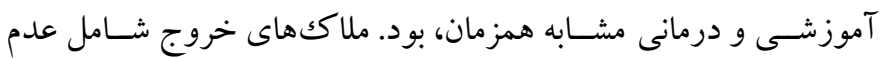
رضايت از شركت در ئزوهش، دريافت درمان دارويى و ساير برنامههاى مهاى

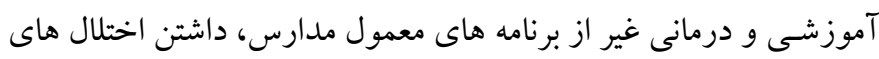

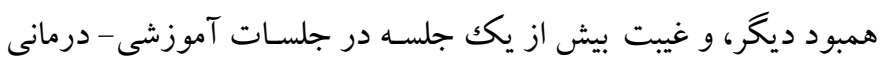

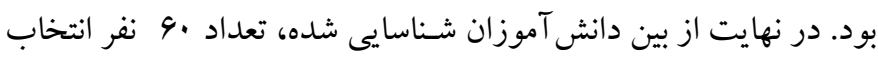

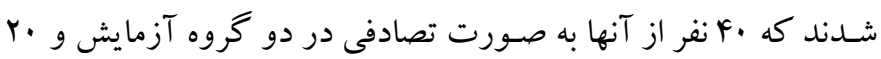

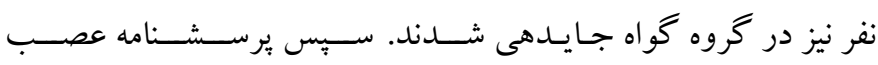
روانشــــاختـى كـانـرز (يـيش آزمون) بين معلمـان اين دانش آموزان

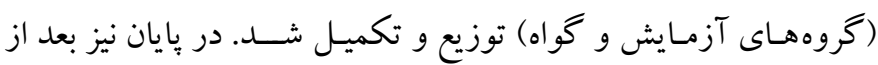

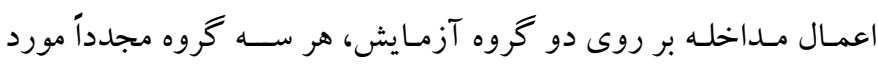

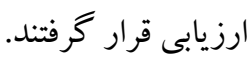

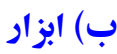

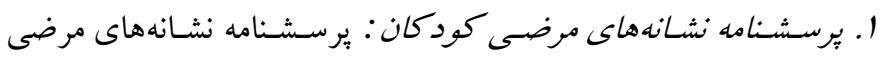
كو دكان يكك مقياس درجهبندى رفتار اســت كه فرم اوليه آن در ســال

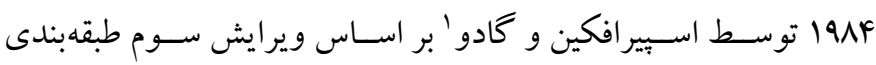

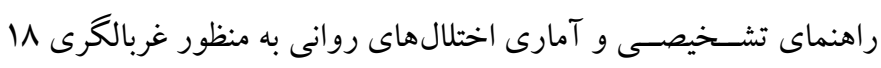

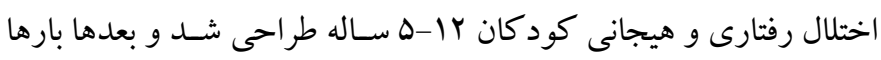

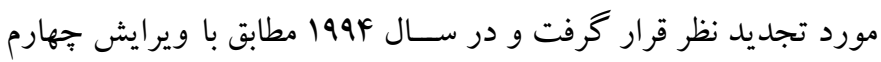

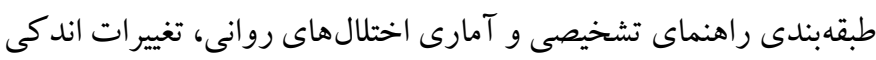
در آن ايجاد شـد و با نام يرسشنامه نشانههاى مرضى كو كود كان منتشر شد. يرسشنامه نشانهاى مرضى كود كان داراى دو فرم والد و معلم است: فرم

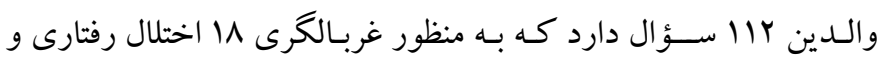
هيجانى تنظيم شـده، و فرم معلم كه حاوى اطلاعاتى از محيط تحصيلى و

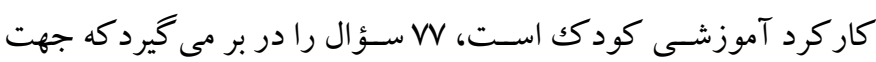
غربال 9 اختلال رفتارى و هيجانى طر احى شده است. برسشنامه نشانه وناى

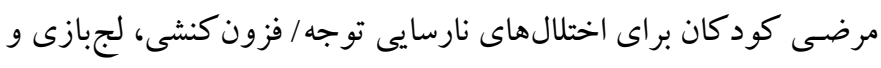

1. Sprafkin \& Gadow

2. The screening cut of score method

3 . The symptom severity score method 
جديدى و عابدى اين يرسـشـنامه در سـال •وسا ترجمه و هنجاريابى

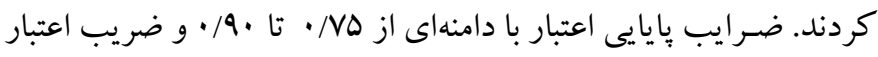

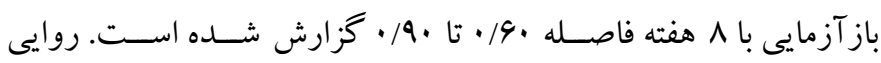
سـازههاى فرمهاى كانرز با اسـتفاده از روشهاى تحليل عو امل به دسـت آمده، و روايى افتراقى آنها با بررسىى آمارى توانايى برسـشـنامه در تمايز افراد مبتلـا بـه اختلـال نـارســايى توجه/فزون كنشــى از بهنجار و ديخر كروههاى بالينيف كاملاً تأييد شده است ( آس). كانرز و همكاران (1999) يايايى اين مقياس را • •/ • و مؤسسه علوم شناختى اعتبار اين برسشنامه را

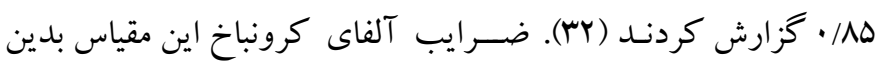
شـرح در اين مطالعه به دسـت آمده اسـت: نمره كل اYY/ • و براى زير

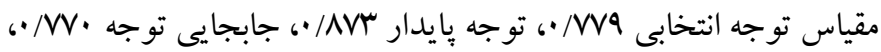
توجه تقسيم شده VAF/ • و فراخناى توجه IVI/ • اعتبار درونى فرم معلم يرسـشنامه كانرز- اوايل كودكى كه توسط آلفاى كرونباخ بررسى شد، براى مقياس كلى و زير مقياس اختلال نارسـايى توجه/ فزون كنشسى 191. به دست آمد. ج) برنامه مداخلهاى: در اين مطالعه يكى از گروههاى آزمايش آموزش بــازىهاى ادراكى - حركتى را در ^ جلسه ه\& دقيقهاى و كروه آزمايش دوم، برنـامـه آموزشــى خودآموزى كلامى رادر ^ جلســه •ه دقيقهاى دريافت كرده است. اين در حالى است كه گروه گو اه هيج مداخلهاى را دريافت نكرده است. محتواى جلسات هر يكك از برنامه هاى مداخلهاى در جدولهاى او Y گز ارش شده است.
روانسـنجى اين فهرسـت را بر روى •4 نمونه بهنجار و 14 نمونه بالينى از كودكان 4 تا Fا سـاله، بررسى كردهاند. بر اساس يافتهها نمره

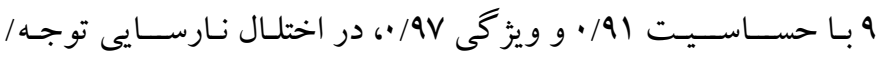
فزون كنشى مى تواند كود كان با و بدون اختلال را غربال كند. ضسريب يايايى باز آزمايى اين يرسـشـنامه براى اختلالهاى گوناكون در دامنهاى

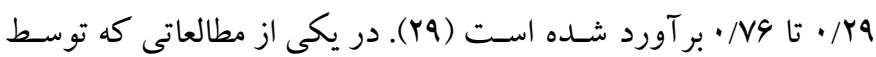
كرايسـون و كارلسـون (1991) بر روى ويرايش سوم برسشنامه نشانهاى مرضـى كود كان انجام گرفت، حســاســـت آن براى اختلال نارســايى

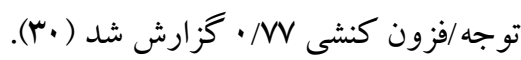
r. مقياس عصب روانشناختى كانرز': در اين بثوهش به منظور ارزيابى دامنه توجه، از خرده مقياس مشكلات توجه مقياس عصبروانشناختى كودك و نوجوان كانرز اسـتفاده شــــ اين مقياس، مشـكلات توجه، عملكرد حسـى حر كتى، زبـان، كنشهاى اجر ايى، حافظه، ياد گيرى، و شـناخت را مىسـنجد و توسط كانرز در سال \& ...Y براى كودكان ه تا r إساله ساخته شده است و در مورد كروهها و اختلالات مختلف مانند اختلالات ياد گيرى، اختلال نارسـايى توجه/فزون كنشـى، اختلال رفتار هنجارى '، و اختلال نافرمانى مقابلهاى مورد اسـتفاده قرار مى گيرد. نوع يرسـشــامه، بسـته ياســخ بوده و ســؤوالات با طيف F ززينهاى (شـديد، متوســط، خفيف، و مشـاهده نشــده) طراحى شـده اسـت. خرده مقياس مشـكلات شـامل \& ا كويه اسـت و توجه انتخابى، توجه يايدار، جابجايى توجه، توجه تقسيم شده، و فراخناى توجه را ارزيابى مى كند.

جدول ا: محتواى جلسات آموزش بـازىهاى ادراكى - حر كتى

\begin{tabular}{|c|c|c|}
\hline 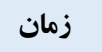 & محتواى آموزش بازى هاى ادراكى - حر كتى & 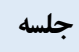 \\
\hline 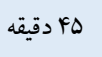 & آشنايى با روش، تشريح هدف و ضرورت مداخله براى والدين، آشنايى كودك با مربى و اتاق بازى & 1 \\
\hline 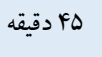 & راه رفتن روى تخته، حفظ تعادل، بريدن، لى لى و عبور از مانع & 1 \\
\hline 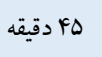 & حركت دادن مداد بين دو خط كه به تدريج تنك تر مىشوند، يافتن تفاوت و تشابه دو شكل & r \\
\hline 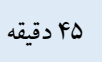 & جيدن دومينو، استفاده از كدها، جيدن مهرههاى رنغخى مانند درمانخر & r \\
\hline 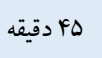 & بازى شباهتها و تفاوتها، لمس اشياء با جشم بسته و تشخيص و رسم آنها & $r$ \\
\hline 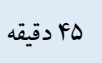 & بازى يازل، نقش از زمينه، اكمال بصرى (كامل كردن شكل) & $r$ \\
\hline 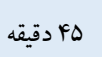 & بازى تانگر ام، بازى روابط فضايى، بازى با جهت ها (جِ، راست، بالا و پِائين) & f \\
\hline
\end{tabular}


FD

P د د P

ه

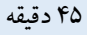

D د د

D د د P

FD

FD
بازى ببين و بحُو و داستانسازى بر اساس تصاوير كتاب، بازى لى لى و نقش از زمينه

بازى تانخرام، قيجى كردن دور اشكال، شناسايى مسير مازها

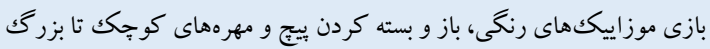

بازى يرتاب دارت، تشخيص اشياء بر اساس صدا، جدا كردن تصاوير با توجه به صداى ابتدا و انتها

بازى تانكرام، يافتن تفاوت و تشابه دو شكل

نخ كردن مهره ها طبق الكو، بازى نقطه نقطه، بازى جهت ها

بازى پِازل، بازى ببين و بكگ و داستانسازى بر اساس تصاوير كتاب

بازى تانگرام، اكمال بصرى (كامل كردن شكل)، شناسايى اشياء مشابه، ييدا كردن تصاوير ينهان، شناسيى مسير مازها f

$\Delta$

$\downarrow$

4

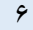

$\checkmark$

V

$\wedge$

جدول זّ: محتواى جلسات آموزش خودآموزى كلامى

\begin{tabular}{|c|c|c|}
\hline زمان & محتوا & جلسه \\
\hline م هوقيقه & ارائه و اجر اي برنامه آموزشى و برنامهريزى به منظور آشنا كردن دانش آموزان با يكديخر. & 1 \\
\hline مه ذزقيه & 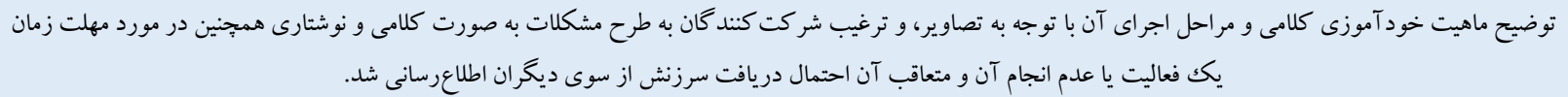 & $r$ \\
\hline ( & لند بيان مى شد و دانش آموزان تمرين را انجام مى دادند. در مرحله سوم، مراحل قبلى را دانش آموزان باصداى & $r$ \\
\hline ( مه ذقيقه & توضيح مرحل اول و دوم خود آموزى كلامى. يعنى در مرحله اول دانش آموزان به گفته هاى يزوهشخر گوش دادند و اعمال وى را مشاهده كردند؛ در مرحله دوم اعمال را انجام & f \\
\hline ( مه ذقيقه. & توضيح مرحله سوم خود آموزى كلامى. دانش آموزان دستورها را با صداى بلند براى خود باز گو مى كردند و در حين باز گو كردن، آنها را انجام مىدادند. & $\Delta$ \\
\hline ( ه ذقيقه & توضيح مرحله جهارم خود آموزى كلامى. دانش آموزان دستورها را با صداى آرام براى خود باز گو و سبس همان دستور را اجر ا مى كردند. & 4 \\
\hline ( ه ذقيقه & توضيح مرحله ينجم خود آموزى كلامى. دانش آموزان دستورها را نجوا مى كردند و در حين نجوا آنها را انجام مىدادند. & $\checkmark$ \\
\hline 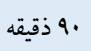 & مراحل ينجگانه خود آموزى كلامى مرور شد. در قسمت تمرين، مراحل ينجگانه خود آموزى كلامى در مورد تكاليف درسى اجرا شد. & $\wedge$ \\
\hline
\end{tabular}

يافته ها

ميانگين و انحراف اسـتاندارد نمرات بيش آزمون و بس آزمون متغيرهاى يزّوهش دو گروه آزمايش بـازى هاى ادراكى - حركتى (كروه آزمايش

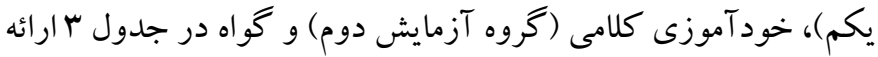

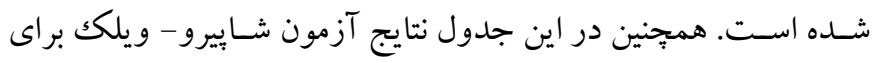

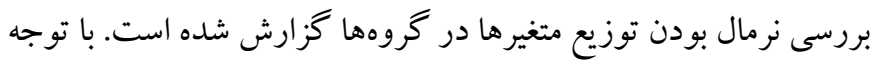
به اين جدول نتايج آزمون شـاييرو -ويلكك براى تمامى متغيرها معنادار

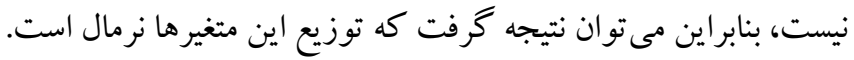

د) روش اجرا: بعــ از كسـبـ مجوزهـاى لـازم اجر ايى و علمى جهـت

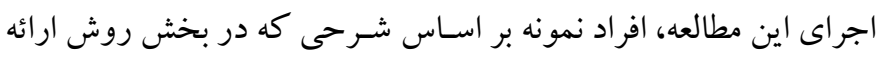

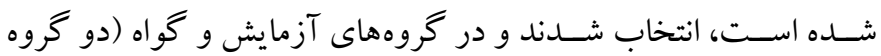

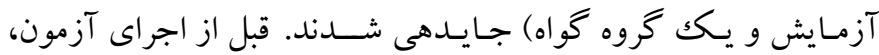
آموزش هاى لازم درباره ويزگى هاى آزمون به معلمان داده شـد تا بتوانند

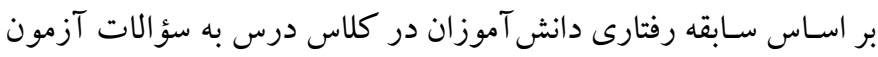

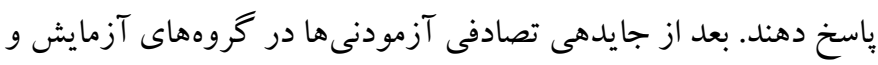

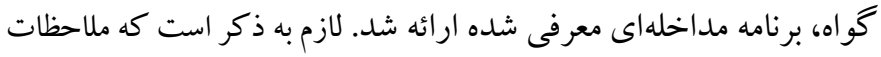

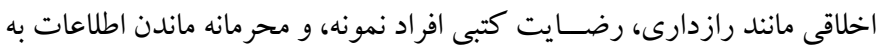

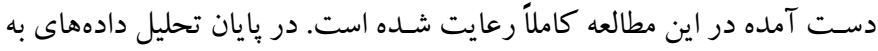
دست آمده با استفاده از شاخصهاى توصيفى و تحليل كوواريانس انجام شد. 
جدول": شاخصهاى توصيفى نمرات بيش آزمون- بِ آزمون در كروههاى آزمايش و كواه

\begin{tabular}{|c|c|c|c|c|c|c|}
\hline $\mathbf{p}$ & شإيرو - ويلك & انحراف استاندارد & ميانگين & كروه & وضعيت & متغير \\
\hline$\cdot / V r$ &.$/ 99$ & $r / Y r$ & $9 / 90$ & ييش آزمون & \multirow{2}{*}{ گروه آزمايشى يكم } & \multirow{6}{*}{ توجه انتخابى } \\
\hline$\cdot / \mathrm{VA}$ & $\cdot / 94$ & $1 / 994$ & $V / 10$ & يس آزمون & & \\
\hline$\cdot / F$ & $\cdot / 91$ & $r / \Delta$ & $1 / 9$ & ييش آزمون & \multirow{2}{*}{ گروه آزمايشى دوم } & \\
\hline$\cdot / V r$ & $\cdot / 94$ & $r / \Delta$ & N/9 & پس آزمون & & \\
\hline$\cdot / \cdot \Delta \Delta$ & $\cdot / M$ & 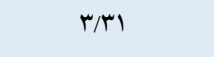 & $\Lambda / \vee$ & بيش آزمون & \multirow{2}{*}{ كروه گواه } & \\
\hline .194 &.$/ 90$ & $r / \Delta$ & N/9 & يس آزمون & & \\
\hline$\cdot / r$ & $\cdot / 9$ & $r / r q$ & $9 / 90$ & ييش آزمون & \multirow{2}{*}{ گروه آزمايشى يكم } & \multirow{6}{*}{ توجه بِايدار } \\
\hline ( ) & . & $1 / 91$ & $V / r$ & يس آزمون & & \\
\hline$\cdot / \Delta \Lambda$ & $\cdot / 90$ & $r / q V$ & $Q / 4 \Delta$ & ييش آزمون & \multirow{2}{*}{ گروه آزمايشى دوم } & \\
\hline$\cdot / \mathrm{V} \wedge$ & $\cdot / 9 V$ & Y/IV & $\mathrm{V} / \mathrm{l}$. & يس آزمون & & \\
\hline$\cdot / / q$ & $\cdot / 9 F$ & r/AG & $9 / \Gamma$ & ييش آزمون & \multirow{2}{*}{ روه گواه } & \\
\hline$\cdot / \Upsilon \Lambda$ & ./ar & $r / q$. & $9 / 10$ & يس آزمون & & \\
\hline$\cdot / r \Delta$ & . /9r & r & 4 & ييش آزمون & \multirow{2}{*}{ كروه آزمايشى يكم } & \multirow{6}{*}{ جابجايى توجه } \\
\hline$\cdot / r$ & $\cdot / 9$ & I/rY & $4 / 90$ & يس آزمون & & \\
\hline$\cdot / f$ & $\cdot / 9 F$ & $1 / 99$ & $9 / 10$ & يِيش آزمون & \multirow{4}{*}{ 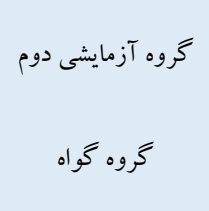 } & \\
\hline.$/ .9$ & $\cdot / 9$ & I/rY & $4 / 90$ & يس آزمون & & \\
\hline$\cdot / \cdot v$ & $\cdot / 19$ & $r / \cdot \Delta$ & $F / V$ & ييش آزمون & & \\
\hline$\cdot / 49$ &.$/ 91$ & r & $\Delta / 10$ & يس آزمون & & \\
\hline$\cdot / r \Delta$ & $\cdot / 9 r$ & $r / \cdot \Delta$ & $9 / \cdot \Delta$ & بيش آزمون & \multirow{2}{*}{ گروه آزمايشى يكم } & \multirow{6}{*}{ توجه تقسيم شده } \\
\hline$\cdot / r \mid$ & $\cdot / 91$ & $1 / \Delta$. & $9 / 1$ & يس آزمون & & \\
\hline$\bullet /$ & $\cdot / \mathrm{M}$ & $1 / 94$ & $9 / 4$ & يِيش آزمون & \multirow{4}{*}{ 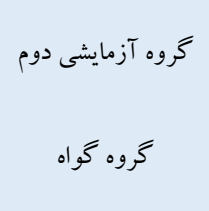 } & \\
\hline$\cdot / 4$ & $\cdot / 94$ & $1 / 4 \Delta$ & $\checkmark$ & يس آزمون & & \\
\hline$\cdot / F r$ &.$/ 90$ & $r / \cdot \Lambda$ & $V / F$ & ي ييش آزمون & & \\
\hline 栏 & $\cdot / 9$. & T/M & $V / q$ & يس آزمون & & \\
\hline ת &.$/ 94$ & $r / \wedge q$ & $9 / 4$ & ييش آزمون & \multirow{2}{*}{ گروه آزمايشى يكم } & \multirow{6}{*}{ فراخناى توجه } \\
\hline$\cdot / 79$ &.$/ 91$ & $1 / 90$ & $9 / 9$ & يس آزمون & & \\
\hline$\cdot / 49$ &.$/ 9$ & r/AY & Q/vQ & ييش آزمون & \multirow{2}{*}{ گروه آزمايشى دوم } & \\
\hline ( &.$/ 94$ & $r / l 1$ & $V / r$ & يس آزمون & & \\
\hline.$/ 11$ &.$/ 91$ & $r / l f$ & $\Lambda / v$ & ييش آزمون & \multirow{2}{*}{ گروه گواه } & \\
\hline$\cdot / \cdot \wedge$ &.$/ 19$ & $r / 4 r$ & $V / 90$ & يس آزمون & & \\
\hline
\end{tabular}

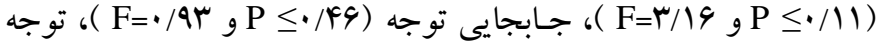

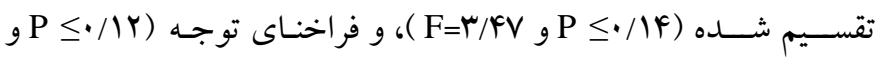

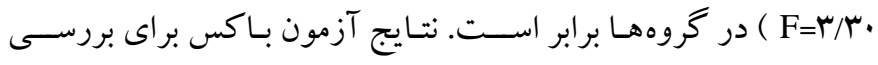

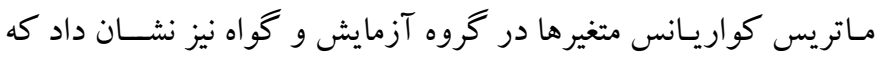

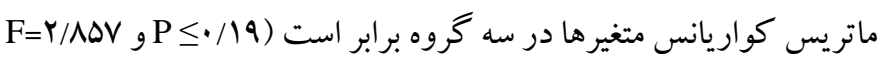

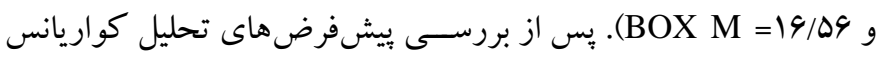
جنــ متغيرى، نتـايج نشــان داد كـه بين مؤلفـهــاى دامنـه توجـه تفاوت
براى بررسى تأثير بازىهاى ادراكى و حركتى و خود آموزى كلامى

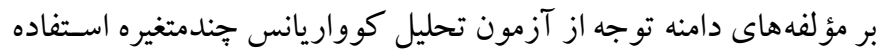

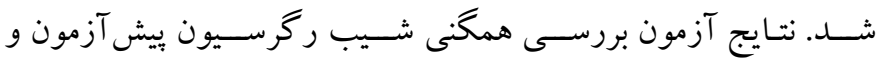

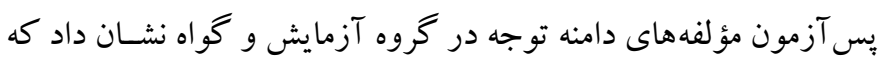

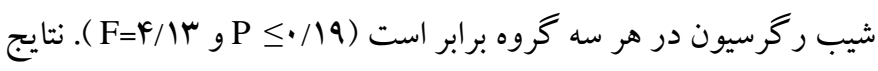

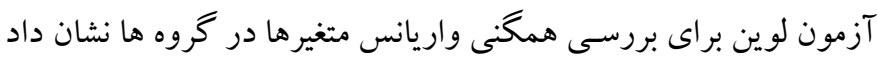
كه واريانس مؤلفههاى توجه انتخابى (F 
جابجايى توجه، وץ درصد جابجايى توجه، و 4س درصد فراخناى توجه را تبيين مى كند.

براى مشـخص كردن تفاوت كروههاى سـه گانه در خردهمقياس هاى دامنه توجه از آزمون LSD استفاده شده است. نتايج به دست آمده در جدول F نشان مىدهد كه در خردهمقياس توجه انتخابى، گرووه بازىهاى

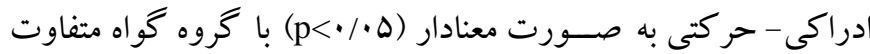

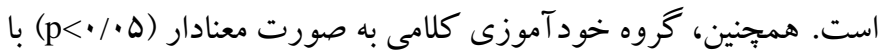
گروه گواه متفاوت اسـت؛ اما اين تفاوت بين كروه بازىهاى ادراكى حركتى و خود آموزى كلـامى، معنـادار نيســت. در خردهمقيـاس توجـه

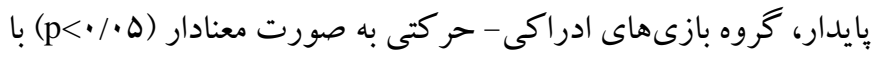

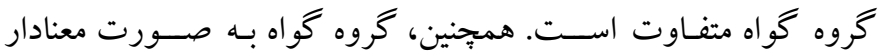
(p<• با كروه خودآموزى كلامى متفاوت است؛ اما اين تفاوت بين گروه بازىهاى ادراكى - حر كتى و خود آموزى كلامى معنادار نيست. در سـاير خردهمقياسهاى دامنه توجه، تفاوت گرووها دو به دو مقايسـه شده
Wilks' Lambda

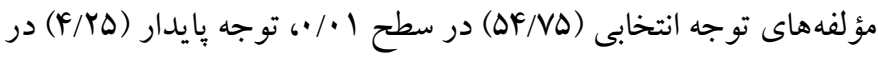

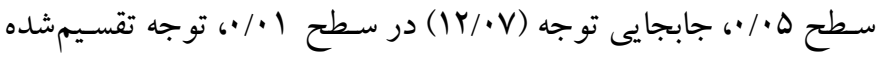

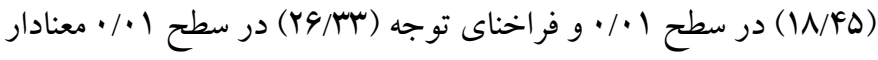
است. اين يافتها نشانكر آن است كه بين گروهها در اين مؤلفهها تفاوت معنادارى وجود دارد. بررسسى ميانگين ها نشـان مىدهد كه ميانگين كروه

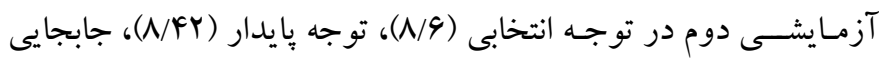

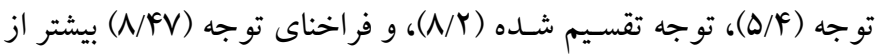
ميـانگين گروه آزمـايشـى اول در اين مؤلفهها به ترتيب (N/Y)، (N/TV)،

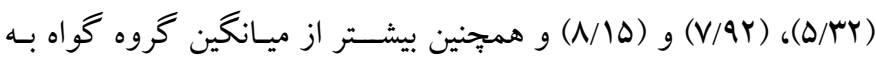

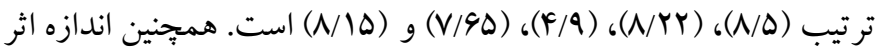

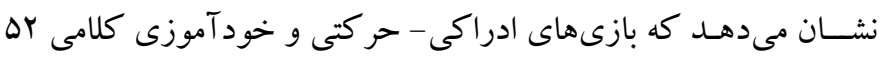
درصسـد از تغييرات توجه انتخابى، ه/9 درصــد توجه پيايدار، 19 درصـــ

جدول ع: نتيجه آزمون LSD براى مقايسه تفاوت ميانغين كروهها در خردهمقياسهاى دامنه توجه

\begin{tabular}{|c|c|c|c|c|c|}
\hline معنادارى & خطاى انحراف استاندار & تفاوت ميانكينها & & كروهها & \\
\hline$\cdot / 1 \cdot \Delta$ & $\cdot / 4 \wedge \Delta$ & $\cdot / \wedge \Delta \wedge$ & خود آموزى كلامى & & \\
\hline.$/ \cdot 1 \pi$ & $\cdot / \mathrm{VVA}$ & 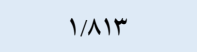 & كروه گواه & بارىها: & توجه انتخابى \\
\hline$\% \cdot r$ & ./VYG & $1 / 949$ & كروه گواه & خود آموزى كلامى & \\
\hline.$/ .94$ &.$/ 011$ &.$/ 9 F V$ & خود آموزى كلامى & & \\
\hline$\cdot / \cdot \uparrow$ & $\cdot / \mathrm{NDI}$ & $1 / A \cdot \Lambda$ & كروه گواه & بارىهاى ام & توجه پِيدار \\
\hline$\% \cdots$ & . & r/vIT & خودآموزى كلامى & كروه گُواه & \\
\hline.$/ \cdot 1$ & - /ArG & r/944 & كروه گواه & خود آموزى كلامى & \\
\hline$\% \mu$ & $\cdot / \mathrm{A} \cdot \mathrm{r}$ & 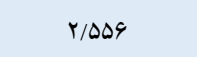 & بازىهاى ادراكى - حر كتى & كروه گواه & جابجايى توجه \\
\hline.$/ \cdots$ & - /AFF & Y/AFI & خود آموزى كلامى & . & \\
\hline$\cdot / \cdot v$ & - /var & $r / F+1$ & بازىهاى ادراكى - حر كتى & تروه قواه & توجه تقسيم شده \\
\hline .1 .94 & $\cdot / 0 \cdot r$ & $. / 9 / f$ & خودآموزى كلامى & بازىهاى ادراكى- حركتى & \\
\hline$\cdot \%$ & - / $\Delta \Delta Q$ & r/Q/T & گرووه گواه & خ & \\
\hline.$/ 1 r$ & - $/$ far & ./V9A & بازىهاى ادراكى - حر كتى & 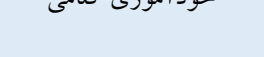 & فراخناى توجه \\
\hline.$/ \cdot r$ & $\cdot /$ VYA & $1 / 994$ & كروه گواه & بازىهاى ادراكى - حر كتى & \\
\hline
\end{tabular}

يس آزمون دامنه توجه در گروههاى آزمايش و كو اه نشـان داد كه شيب

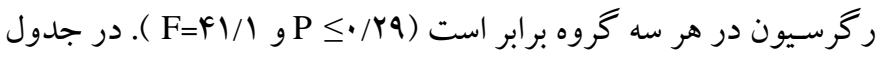
ه نتـايج تحليـل كواريـانس تككتمتيرى براى بررسـى تفاوت كروههاى
براى بررسـى تأثير آموزش ادراكى- حركتى و روش خودآموزى كلـامى بر دامنـه توجـه دانش آموزان از تحليـل كوواريـانس تككمتغيره اسـتفاده شـد. نتايج آزمون بررسى همخنى شيب رگرسيون بيش آزمون و 
(YN/TNN)

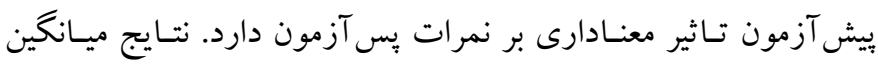

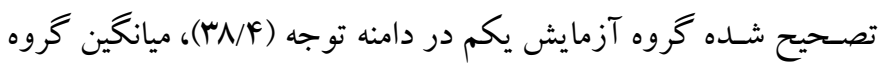

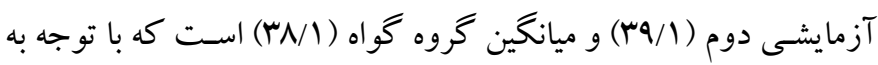

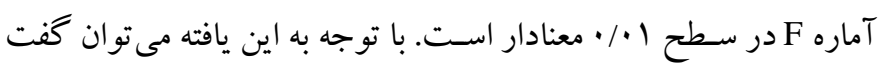

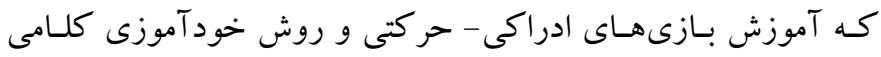

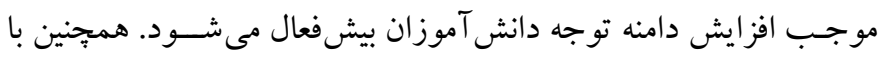

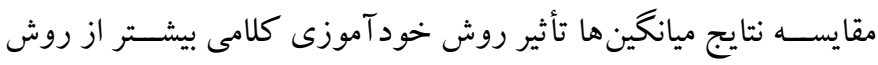
بازىهاى ادراكى - حركتى است.
آزمـايش و گو اه در يِيش آزمون و يس آزمون متغير دامنه توجـه گزارش شده است كه نشان مىدهد تعامل بين شرايط و ييش آزمون معنادار نيست

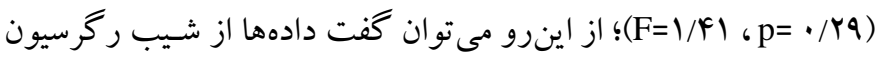

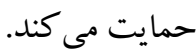
با توجه به جدول ه آماره F دامنه توجه در يس آزمون (

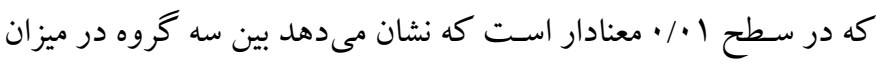
دامنه توجه تفاوت معنادارى وجود دارد. همجنين اندازه اثر نشان مىدهد

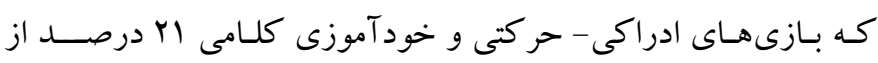

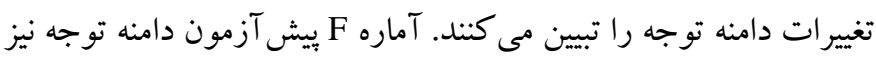

جدول 0: نتايج تحليل كوواريانس تكتمتغيرى براى بررسى تفاوت كروههاى آزمايش و كواه در دامنه توجه

\begin{tabular}{|c|c|c|c|c|c|c|c|}
\hline Eta & sig & $\mathbf{F}$ & MS & df & Ss & منابع تغيير & متغير \\
\hline \multirow{4}{*}{ ו ו וא/. } & & & & 1 & | $9 \mathrm{VD} / \cdot \mathrm{r \Delta}$ & يِيش آزمون & \multirow{4}{*}{ دامنه توجه } \\
\hline & $\cdot / \cdots$ & YN/YN & 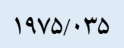 & $r$ & V9N/. & كروه & \\
\hline & $\cdot / \cdots$ & $|\Delta / \Delta|$ & $r \wedge F / \cdot 1$ & $\Delta 9$ & $\mathrm{r} \wedge 9 \mathrm{~V} / .90$ & خطا & \\
\hline & & & & 4. & vavi. & كل & \\
\hline
\end{tabular}

به منظور فهم تفاوت گرووهاى ســ گانه از آزمون LSD اسـتفاده شده است كه نتايج در جدول 4 گزارش شده است.

جدول 7: نتيجه آزمون LSD براى مقايسه تفاوت ميانغين كروه

\begin{tabular}{|c|c|c|c|c|}
\hline معنادارى & خطاى انحر اف استاندار & تفاوت ميانكينها & & \\
\hline$\cdot / \mu r$ & $r / F V q$ & V/Vq. & خودآموزى كلامى & \multirow{2}{*}{ كروه گو اه } \\
\hline$\cdot / \cdot \cdot 1$ & r/Far & $N / 9 V 1$ & بازىهاى ادراكى - حركتى & \\
\hline$\cdot / V Y I$ & $r / F \Delta V$ & $-\cdot|M \wedge|$ & خودآموزى كلامى & بازىهاى ادراكى - حركتى \\
\hline
\end{tabular}

با اختلال نارسـايى توجه/ فزون كنشى بود. با توجه به يافتهاى به دست

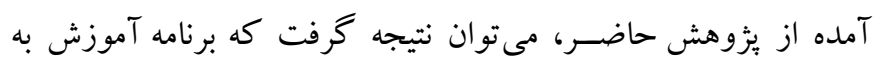

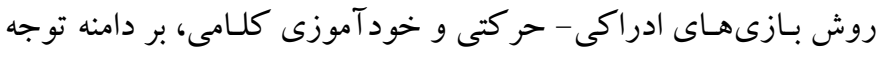
دانش آموزان در سطح معنادارى 1. /. تأثير گذار بوده است. در اين ميان

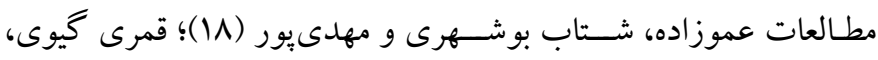

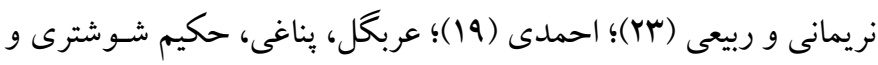
حبرانى (YY)؛ ورت و همكاران (Yצ)؛ اتنر، اسميت، كايين، و لابان (Y) (Y)؛

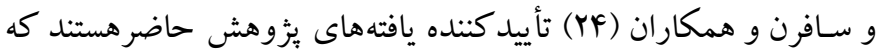
هر كدام در مطالعات خود به اين نتيجه رسـيدند كه بازىهاى ادراكى -
نتايج به دست آمده در جدول 4 نشان مىدهد گروه گو اه به صورت

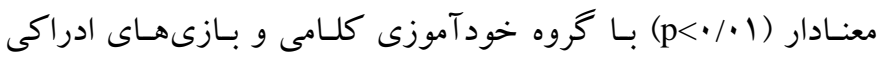
حر كتى متفاوت است و دانش آموزان گروه ادراكى - حر كتى، عملكرد

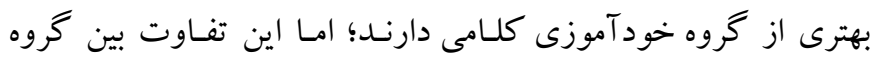
خودآموزى كلامى و بازى هاى ادراكى - حر كتى معنادار نيست.

\section{بحث و نتيجه كيرى}

هدف يزووهش حاضـر مقايسـه اثربخشسى آموزش به روش بازىهاى

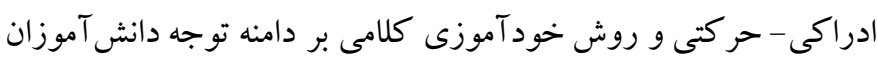


ورزشىى، اهميت بيشـترى بدهند. همجنين از متخصـصـان تربيت بلنى و كاردرمانى در مدارس به خصـوص در مدارس با نيازهاى ويزه مقطع ابتدايى به صسورت تماموقت اسـتفاده شود و به والدين نيز آموزش هاى لـازم در جهـت تقويست مهارتهاى حركتى و بازيرورى حسـى و حر كتيكود كان، ارائه شود.

همجينين مقايسـه نتايج اين دو روش مداخله در اين مطالعه نشـان داد تـأثير آموزش به روش بازىهاى ادراكى - حركتى بيشــتر از آموزش به روش خودآموزى كلامى بر دامنه توجه دانش آموزان بااختلال نارســايى توجـه / فزون كنشــى، مؤثر بوده اســت. اين نتيجـه نيز با يافته هاى برخى

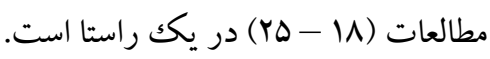
در تبيين اين نتايج بايد ابتدا اين موضــوع را مورد توجه قرار داد كه كودكـان مبتلـا بـه اختلــال نـارســايى توجه / فزون كنشــى در فرايندهاى ادراكى، حر كتى، و شـناختى، دجار آسيب هستند (·Y) و به دليل اهميت تجربـهـهـاى حر كتى كســب شــده در ســـين اوليـه، مطابق با يافتهاى يثزوهشهـاى مختلف مىتوان كفت كه ادراكك از همان ابتدا تحت تأثير حر كت قرار مى گيرد و حركت نيز به نوبه خود بر ادراك تأثير مى كذارد. از اين رو برخوردارى كود كان از يكك زمينه غنى و اسـتوار از تجربههاى ادراكى - حر كتى موجب رشـد بردازش بينايى - فضايى در كود كان شده و بهبود ادراكك بينايى - فضايى مى تو اند منجر به تحول فر ايندهاى شناختى كود كان مانند توجه شــه و در يادگيرىهاى آموزشـكاهى تاثير زيادى بحذارد (19). همجينين نتايج اين بزوهش نشان داد كه روش خود آموزى

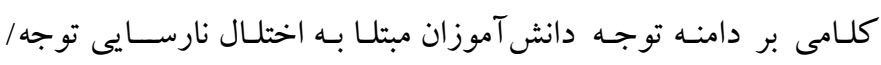
فزون كنشـى مؤثر اســت. اين نتايج با يافتهاى يثزوهش هاى قصــابى، تجريشى و مير زمانى (سا) و مطالعه بارت و اولنديك (19) همسو است.

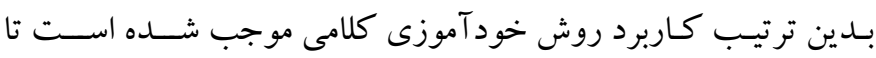
كود كان مبتلا به اختلال نارسـايى توجه / فزون كنشـى بتو انند بر مشـكلات توجه فائق آيند و حواس و دقت خود را بالاتر ببرند. از سـوى ديخر، اين روش ســبب مىشــود تا كود كان مبتلا به اختلال نارســايى توجه / فزون كنشى بتوانند گفتار درونى خود را فعال نخه دارند و در انتخاب ياسخها، دقت للازم را داشته و كمتر دجار حواسبرتى شوند. از محدويتهاى تحقيق حاضـر مى توان به عدم قابليت تعميم نتايج

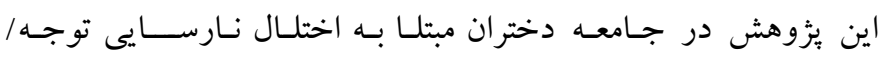

حـركتى و روش خودآموزى كلـامى بر دامنسه توجسه دانش آموزان تاثير گذار بوده است.

در تبيين اثربخشى تكنيك خودآموزى كلامى مىتوان به اين نكته اشـاره كرد كه دانش آموزان با بهره گيرى از اين برنامه، مشكلات توجه و تمركز خود را بهبود مىبخشــند. تأثير آموزش خودآموزى كلامى به دليل افزايش توانايى كفتار درونى و محرمانه اسـت كه از طريق آن، كودك قادر به بازدارى ياســخ هاى نيرومند قبلى مىشــود و موجب

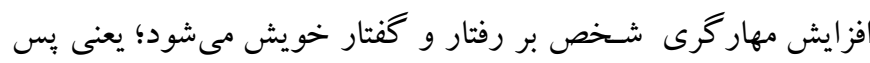
از روبرو شدن با محر كك، انديشيده و ياسخ مناسبترى را ارائه مى كند. در مجموع، روش خود آموزى كلامى به شـكل گيرى تفكر كلامى منتهى مىشـود كه به واسـطه آن كودكك مبتلا به ناتوانى ياد گيرى قادر مىشـود رفتار خويش را خصوصى و درونى سازد تا به بيشبينى آينده و به حداكثر رسـاندن يِامدهاى بلندمدت نائل شـود. فعال شـدن خفتار درونى در نتيجهـ آموزش خودآموزى كلامى، به مثابه نقطه اتكا در برخورد با مشـكلات توجه، عمل مى كند و با آموزش روش مقابله با سـبك هاى شـناختى نامناسـب به دانش آموزان، آنها را قادر مىسـازد از طريق حرف زدن با خود به مهار و هدايت صحيح حواس و تلاش ذهنى در انجام امور خويش، مبادرت ورزند. روش ادراكى - حر كتى در شـكل يذيرى سـيستم عصبى نقش مهمى دارد. با اين حالبيشـتر مطالعات انجام شـده مربوط به افراد بدون اختلال، يا افرادى با اختلالات ديخر اســت. بر اســاس اين مطالعات تمرينات

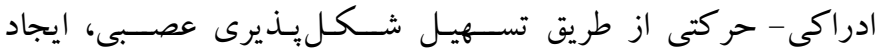
سـاختارهاى جديد سـينايسى، كاهش اختلالات شناختى، افزايش ادراك بصسرى به وسـيله افزايش سـيكُال بهرهورى بينايى (YV)، بهبود سـلامت شـــــاختى و عصــبى، افزايش عملكرد بردازش اطلـاعـات، افزايش بهرهورى انتقالدهندهاى عصسبى، سـاز گارى عصسبى، بازيابى عملكرد رفتارى، و تنظيم هيجان مى تواند بهرهورى فيزيولوزى عصسبى، تحول مغز، و تحول حر كتى را بهبود بخشــ و باعث افزايش عملكرد سـيسـتم عصـبى و عملكرد شــاختى شــود (Y^). در نتيجه بازىهاى ادراكى حر كتى در مقايسه با روش خود آموزى كلامى، اثر بخشى بهترى بر دامنه توجه دانش آموزان فزون كنش دارد. در اين ارتباط به مؤسسات آموزشى و بالينى بيشــهاد مىشــود به سـاعت درس تربيت بلدنى و فعاليتهاى 
تشـكر و قدردانى: اين مقاله بر گرفته از رسـاله دكتراى تخصصى (تصويب

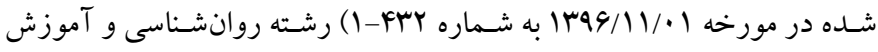

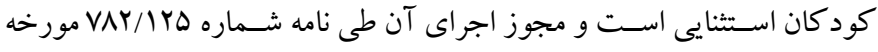

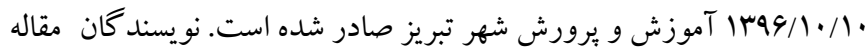
بر خود لازم مىدانند كه از همكارى دانش آموزان، معلمان آنها، و همجنين بردين

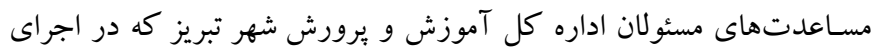
اين يزوهش نقش مهمى داشتند، تشكر و قدردانى كنند.

تضـاد منافع: اين يُوهش بدون حمايت مالى سـازمان يا نهاد خاصسى انجام كرفته است و بنابر اين تضاد منافع ندارد.
فزون كنشىى، عدم اسـتفاده از فرم والدين برسـشـنامه نشـانه هاى مرضى

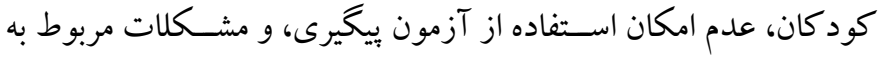
اســاندارد نبودن مكان آموزش برنامه خود آموزى كلامى، اشــاره كرد. بــدين ترتيـب بيشــنهـاد مى شــود در مطـالعـات آتى ضــمن رفع اين محـدوديتهاى روششــناختى، اثربخشـى روشهاى مداخلهاى به كار

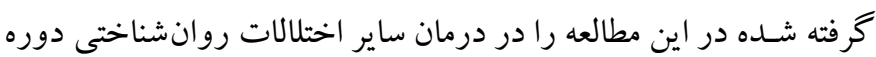
كودكى بررسى كنند. 


\section{References}

1. American Psychiatric Association. Diagnostic and statistical manual of mental disorders (DSM-5®). American Psychiatric Pub; 2013, pp: 217-352. [Link]

2. Polanczyk G, De Lima MS, Horta BL, Biederman J, Rohde LA. The worldwide prevalence of ADHD: a systematic review and metaregression analysis. Am J Psychiatry. 2007; 164(6): 942-948. [Link]

3. Gaastra GF, Groen Y, Tucha L, Tucha O. The effects of classroom interventions on off-task and disruptive classroom behavior in children with symptoms of attention-deficit/hyperactivity disorder: A metaanalytic review. PLoS ONE. 2016; 11(2): e0148841. [Link]

4. Johnston C, Mash EJ, Miller N, Ninowski JE. Parenting in adults with attention-deficit/hyperactivity disorder (ADHD). Clin Psychol Rev. 2012; 32(4): 215-228. [Link]

5. Bussing R, Zima BT, Mason DM, Meyer JM, White K, Garvan CW. ADHD knowledge, perceptions, and information sources: Perspectives from a community sample of adolescents and their parents. J Adolesc Health. 2012; 51(6): 593-600. [Link]

6. Barkley RA. Adolescents with attentiondeficit/hyperactivity disorder: An overview of empirically based treatments. J Psychiatr Pract. 2004; 10(1): 39-56. [Link]

7. Frazier TW, Youngstrom EA, Glutting JJ, Watkins MW. ADHD and achievement: Meta-Analysis of the child, adolescent, and adult literatures and a concomitant study with college students. J Learn Disabil. 2007; 40(1): 49-65. [Link]

8. Reid R, Maag JW, Vasa SF, Wright G. Who are the children with attention deficit-hyperactivity disorder? A school-based survey. J Spec Educ. 1994; 28(2): 117-137. [Link]

9. Finzi-Dottan R, Triwitz YS, Golubchik P. Predictors of stress-related growth in parents of children with ADHD. Res Dev Disabil. 2011; 32(2): 510-519. [Link]

10. Demaray MK, Schaefer K, Delong LK. Attentiondeficit/hyperactivity disorder (ADHD): A national survey of training and current assessment practices in the schools. Psychol Sch. 2003; 40(6): 583-597. [Link]

11. Ocasio W. Attention to attention. Organization Science. 2010; 22(5): 1286-1296. [Link]

12. Sobhi N. The effectiveness of verbal self instruction method on improving the emotional processing and social skill of students with specific learning disorder.
Journal of Learning Disabilities. 2016; 5(3): 71-88. [Persian]. [Link]

13. Ghasabi S, Tajrishi M, Mir Zamani SM. The effect of verbal self-instruction training on decreasing impulsivity symptoms in ADHD children. Journal of Developmental Psychology, Iranian Psychologists. 2009; 5(19): 209-220. [Persian]. [Link]

14. Ronen T. Imparting self-control skills to decrease aggressive behavior in a 12-year-old boy: A case study. Journal of Social Work. 2004; 4(3): 269-288. [Link]

15. Seligman MEP. Positive psychology in practice. Linley PA, Joseph S, editors. Edición: 1. Hoboken, N.J: Wiley; 2004, pp: 146-148. [Link]

16. Barrett PM, Ollendick TH. Handbook of interventions that work with children and adolescents: Prevention and treatment. John Wiley \& Sons; 2004, pp: 88-91. [Link]

17. Amouzadeh F, Hasanvand S, Hashemiyan K, Hemayattalab R. A comparison between effects of game and pharmacotherapy upon the improvement of the attention span and gross motor skills in children with attention deficit hyperactivity disorder (ADHD). Motor Behavior. 2016; 8(23): 97-110. [Persian]. [Link]

18. Amouzadeh F, ShetabBoushehri N, Mehdi Pur A. The effect of the school games on the locomotor skills of male students suffering from attention deficit hyperactivity disorder (ADHD). Yafteh. 2013; 15(1): 83-91. [Persian]. [Link]

19. Ahmady A. Effect of perceptual-motor practices on motor and mathematical skills in autism, a singlesubject design. Journal of Fundamentals of Mental Health. 2010; 12(46): 534-541. [Persian]. [Link]

20. Jepsen RH, VonThaden K. The effect of cognitive education on the performance of students with neurological developmental disabilities. NeuroRehabilitation. 2002; 17(3): 201-209. [Link]

21. Biederman J, Mick E, Fried R, Wilner N, Spencer TJ, Faraone SV. Are stimulants effective in the treatment of executive function deficits? Results from a randomized double blind study of OROSmethylphenidate in adults with ADHD. Eur Neuropsychopharmacol. 2011; 21(7): 508-515. [Link]

22. Arabgol F, Panaghi L, Hakim-Shooshtari M, Hebrani P. Six week open-label reboxetine treatment in children and adolescents with attention deficit hyperactivity disorder. Tehran University Medical Journal TUMS Publications. 2007; 65(9): 41-46. [Persian]. [Link] 
23. Ghamari Givi H, Narimani M, Rabiee Z. Comparison of executive functions among children with attention deficit hyperactivity disorder, learning disability and normal children. Journal of Fundamentals of Mental Health. 2010; 11(44): 322-333. [Persian]. [Link]

24. Safren SA, Otto MW, Sprich S, Winett CL, Wilens TE, Biederman J. Cognitive-behavioral therapy for ADHD in medication-treated adults with continued symptoms. Behav Res Ther. 2005; 43(7): 831-842. [Link]

25. Etnier J, Smith A, Gapin J, Labban J. Physical activity and cognitive performance in children with attention deficit hyperactivity disorder (ADHD)-Symposium overview. Journal of Sport \& Exercise Psychology. 2009; 31: S11. [Link]

26. Verret C, Guay M-C, Berthiaume C, Gardiner P, Béliveau L. A physical activity program improves behavior and cognitive functions in children with ADHD: An exploratory study. J Atten Disord. 2012; 16(1): 71-80. [Link]

27. Norton DJ, McBain RK, Öngür D, Chen Y. Perceptual training strongly improves visual motion perception in schizophrenia. Brain Cogn. 2011; 77(2): 248-256. [Link]
28. Shahbazi S, Khazaei AA, Aghdasi MT, Yazdanbakhsh K. Effectiveness of perceptual - motor training on motor proficiency children with hyperactivity disorder. Journal of Modern Rehabilitation. 2016; 9(6): 51-59. [Persian]. [Link]

29. Mohamadesmaiel E, Alipour A. A preliminary study on the reliability, validity and cut off points of the disorders of children symptom inventory-4 (CSI-4). Journal of Exceptional Children. 2002; 2(3): 239-254. [Persian]. [Link]

30. Grayson P, Carlson GA. The utility of a DSM-III-Rbased checklist in screening child psychiatric patients. J Am Acad Child Adolesc Psychiatry. 1991; 30(4): 669-673. [Link]

31. Eghbali, A., Moghanni, A. The Effect of Selfregulated Learning Based on Pintrich Model on Problem Solving / Planning / Organizing and Behavioral / Emotional Organization in Elementary Male Students with Reading Disabilities. Journal of Modern Psychological Researches, 2018; 13(50): 6785. [Persian] [Link]

32. Conners, C. (1997).Conners' rating scale: Revised technical manual. North Tonawanda (NY); Available from URL: http: //www. mhs. com[Assessed 2008 Mar 3] [Link]. 